\title{
Selenium in plants and its effect on feeding and development of phytophages
}

\section{Selen w roślinach i jego wpływ na żerowanie i rozwój fitofagów}

\author{
Sabina Łukaszewicz* , Barbara Politycka
}

\section{Summary}

Plant organisms are exposed to various biotic and abiotic stress factors, which cause oxidative stress consisting in the imbalance between the formation and removal of reactive oxygen species, causing damage to cell components. It has been observed that the accumulation of trace elements such as arsenic, cadmium, nickel, zinc and selenium is one of the plants defence strategies against phytophages and it is termed as Elemental Defence Hypothesis. Included in the trace elements, selenium is taken up from the soil by plants and included in their metabolism along sulphur transport and transformation pathways. This element in low concentration supports the resistance of plants to various stress factors by affecting the elements of the antioxidant system. Selenium contained in plants can also act on as a deterrent to phytophages or feeding them toxins and disrupting their development cycle.

Key words: phytophages, trace elements, selenium, plant, toxicity

\section{Streszczenie}

Organizmy roślinne narażone są na działanie różnych biotycznych i abiotycznych czynników stresowych, które powodują stres oksydacyjny polegający na zachwianiu równowagi pomiędzy tworzeniem a usuwaniem reaktywnych form tlenu, powodujących uszkodzenia składników komórki. Zaobserwowano, że akumulacja pierwiastków śladowych, takich jak arsen, kadm, nikiel, cynk oraz selen, stanowi jedną ze strategii obronnych roślin przed fitofagami i jest określana terminem Elemental Defense Hypothesis. Zaliczany do pierwiastków śladowych selen jest pobierany z gleby przez rośliny oraz włączany w ich metabolizm na szlakach transportu i przemian siarki. Pierwiastek ten w niskiej koncentracji wspomaga odporność roślin na działanie różnych czynników stresowych, poprzez wpływ na elementy systemu antyoksydacyjnego. Selen zawarty w roślinach może też działać na żerujące fitofagi deterentnie lub toksycznie oraz zaburzać ich cykl rozwojowy.

Słowa kluczowe: fitofagi, pierwiastki śladowe, selen, roślina, toksyczność

Uniwersytet Przyrodniczy w Poznaniu

Wydział Ogrodnictwa i Architektury Krajobrazu

Katedra Fizjologii Roślin

Wołyńska 35, 60-637 Poznań

*corresponging author: sabina.lukaszewicz@gmail.com

ORCID: 0000-0001-5401-7965 


\section{Wstęp / Introduction}

Niezbędność selenu dla roślin nie została potwierdzona, jednakże pierwiastek ten w niskim stężeniu może stymulować ich wzrost, korzystnie wpływać na proces kiełkowania, opóźniać proces starzenia, jak również łagodzić lub przeciwdziałać skutkom działania na rośliny abiotycznych i biotycznych czynników stresowych (Pilon-Smits i Quinn 2010; Handa 2016). Aktywność biologiczna selenu oraz jego wpływ na organizmy, zależne są od koncentracji tego pierwiastka. Śladowe ilości selenu mogą być pomocne w utrzymaniu homeostazy, natomiast wysoka koncentracja może powodować efekt toksyczny (Hawrylak-Nowak 2015; Handa 2016; Lima i wsp. 2018).

Ze względu na niezbędność selenu dla organizmów zwierzęcych oraz dla człowieka, niedobory tego pierwiastka można uzupełniać suplementami, jednak korzystniejsze jest dostarczanie selenu z żywnością pochodzenia roślinnego. Dlatego gleby ubogie w selen są wzbogacane o ten pierwiastek poprzez nawożenie i prowadzone są badania nad biofortyfikacją roślin selenem dostarczonym doglebowo lub dolistnie (Ros i wsp. 2016). Biofortyfikacja roślin jest metodą produkcji oraz hodowli roślin polegającą na wzbogacaniu surowców roślinnych w składniki mineralne korzystne dla konsumenta (Smoleń i wsp. 2016). Prowadzono badania nad wzbogaceniem w selen gatunków o największym znaczeniu gospodarczym, tj. pszenicy twardej (Triticum durum Desf.) (Poblacionesa i wsp. 2014) i pszenicy zwyczajnej (Triticum aestivum L.) (Broadley i wsp. 2010), soczewicy jadalnej (Lens culinaris) (Thavarajah i wsp. 2008), kukurydzy (Chilimba i wsp. 2012; Jianwei i wsp. 2013), ryżu (Lidon i wsp. 2018), jak również innych gatunków, jak marchew i brokuły (Bañuelos i wsp. 2015) oraz sałata (Ramos i wsp. 2010; Smoleń i wsp. 2016).

Trudno jest jednak przewidzieć, w jaki sposób żywienie roślin selenem wpłynie na żerujące na nich fitofagi. Deterentny, bądź toksyczny wpływ selenu na fitofagi przy korzyściach płynących z biofortyfikacji tym pierwiastkiem dla człowieka oraz dla rośliny, może stanowić dodatkową wartość dla integrowanej ochrony roślin.

\section{Selen $\mathrm{w}$ roślinach / Selenium in plants}

W roślinach zawierających selenocysteinę, selen występuje w tzw. selenobiałkach (Pilon-Smits i Quinn 2010). Wpływa to na ich właściwości - niższą stałą dysocjacji, większą reaktywność i odporność na trwałe utlenianie (Tobe i Mihara 2018; White 2018). Korzyści płynące z modyfikacji tych cech mogły spowodować ewolucję selenoprotein w niektórych organizmach przy odpowiednim zaopatrzeniu w selen (Reich i Hondal 2016; Schomburg i Arner 2017; White 2018). Do selenoprotein należą peroksydaza glutationowa i reduktaza tioredoksyny, pełniące ważne funkcje w usuwaniu reaktywnych form tlenu oraz ochronie przed stresem oksydacyjnym (Pilon-Smits 2015; Gupta i Gupta 2017). Przeciętna zawartość selenu w glebie waha się od 0,01-2 mg/kg suchej masy (s.m.), natomiast gleby bogate w selen zawierają 2-1200 mg Se/kg (White 2018). Rośliny różnią się zdolnością do pobierania i akumulowania selenu w swoich komórkach, co zdecydowało o podziale roślin na trzy grupy: hiperakumulatory, drugorzędowe akumulatory oraz rośliny, które selenu nie akumulują (Galeas i wsp. 2007; Bodnar i wsp. 2012; White 2018).

Autorzy klasyfikacji wskazują różne zakresy akumulacji selenu w poszczególnych grupach roślin. Według klasyfikacji przedstawionej w pracy Bodnar i wsp. (2012) hiperakumulatory gromadzą w swoich komórkach od 1000 do nawet $20000 \mathrm{mg} \mathrm{Se} / \mathrm{kg}$ s.m. Natomiast Galeas i wsp. (2007) podają, iż hiperakumulatory gromadzą od 1000-5000 mg Se/kg s.m., tj. 0,1-0,5\%.

Rośliny będące hiperakumulatorami selenu występują na glebach zawierających więcej niż 10 mg Se/kg s.m. (Galeas i wsp. 2007). Do hiperakumulatorów zalicza się rośliny z rodzaju Stanleya, Astragalus, Conopsis, Neptunia, Xylorhiza, Machaeranthera, jak również gatunki, takie jak: Allium sativum, Brassica juncea, Brassica napus, Brassica oleracea var. italica (Bodnar i wsp. 2012; Gupta i Gupta 2017). Rośliny te wykształciły strategie, dzięki którym zapobiegają toksyczności selenu. Zwiększona tolerancja hiperakumulatorów na wysokie stężenia selenu jest związana z metylacją selenocysteiny oraz selenometioniny, w wyniku której powstaje lotny dimetylodiselenek, co zapobiega włączaniu tych aminokwasów do białek (Brown i Shrift 1981; LeDuc i wsp. 2004; Quinn i wsp. 2010; Gupta i Gupta 2017).

Drugorzędowymi akumulatorami selenu nazywa się rośliny gromadzące selen i niewykazujące objawów toksyczności przy koncentracji 100-1000 mg Se/kg s.m. (Gupta i Gupta 2017). Według Bodnar i wsp. (2012) ta grupa roślin zdolna jest do akumulacji niewielkiej ilości selenu - od 50 do 100 mg Se/kg s.m., natomiast według White (2018) są to rośliny, które mogą tolerować stężenia selenu około $1 \mathrm{mg} \mathrm{Se} / \mathrm{kg}$ s.m. Akumulatory drugorzędowe zasiedlają zarówno gleby ubogie w selen, jak i gleby z wysoką zawartością selenu (White 2018). Rośliny te nazywane są również „wskaźnikami selenu” (Jason i wsp. 2018; White 2018). Zalicza się do tej grupy m.in. gatunki, takie jak Medicago sativa, Camelina microcarpa, Astragalus americanus, Descurainia pinnata oraz gatunki z rodzaju Aster, Camelina, Helianthus, Grinolelia, Melilotus, Atriplex, Castilleja i Gutierrezia (Bodnar i wsp. 2012; Gupta i Gupta 2017). Zgodnie z klasyfikacją przedstawioną przez Bodnar i wsp. (2012) gatunki, takie jak: Brassica juncea, Brassica napus, Brassica oleracea var. italica należą do hiperakumulatorów, natomiast w opinii Gupty i Gupty (2017) należą do drugorzędowych akumulatorów selenu.

Rośliny niebędące akumulatorami selenu zawierają mniej niż 100 mg Se/kg s.m. według Gupty i Gupty 
(2017), natomiast według Bodnar i wsp. (2012) mniej niż $1 \mathrm{mg} \mathrm{Se} / \mathrm{kg}$ s.m. Zgodnie z klasyfikacją White'a (2018), rośliny nieakumulujące selenu nie tolerują w swoich tkankach koncentracji tego pierwiastka powyżej 10-100 mg Se/kg s.m. Do tej grupy zalicza się m.in. gatunki z rodziny Poaceae. Obecność selenu w środowisku glebowym roślin nieakumulujących selenu może ograniczać, a nawet uniemożliwiać ich wzrost (Galeas i wsp. 2007; Bodnar i wsp. 2012; White 2018). Rośliny te uwalniają selen w postaci lotnego dimetyloselenku.

\section{Forma selenu a jego pobieranie i transport w roślinie / The form of selenium and uptake and transport in the plant}

Selen może być pobierany z roztworu glebowego przez komórki korzeni roślin w postaci związków organicznych (selenocysteiny i selenometioniny) oraz w formie jonów mineralnych, różniących się stopniem utlenienia - seleninu (Se IV) oraz selenianu (Se VI) (White 2018). Pobierany przez rośliny selen $\mathrm{w}$ formie selenianu konkuruje o transport z siarką (Jason i wsp. 2018). Selen w formie selenianu pobierany jest przez komórki korzenia na zasadzie transportu aktywnego, wbrew gradientowi potencjału elektrochemicznego, wykorzystując transportery błonowe siarki (Terry i wsp. 2000). Stwierdzono, iż selenian i siarczan konkurują o transportery siarczanu SULTR 1;2 zlokalizowane w korzeniach (El Kassis i wsp. 2007; Sabbagh i Van Hoewyk 2012). Absorpcja selenu kosztem siarki zależy od gatunku rośliny, jak również od stanu odżywienia rośliny (White i wsp. 2004). Wykazano, iż hiperakumulatory selenu mają zwiększoną ekspresję genów odpowiedzialnych za transport i asymilację siarki oraz mogą posiadać transportery o wyższym powinowactwie do selenianu niż do siarczanu (Lima i wsp. 2018). Przypuszcza się, iż w pobieraniu selenu w formie selenianu uczestniczą transportery wysokiego powinowactwa występujące głównie w komórkach korzenia (Handa 2016). Ekspresja genów kodujących transportery wysokiego powinowactwa zależy od zawartości siarki w roślinie, jak również regulowana jest przez poziom glutationu oraz O-acetyloseryny. Transkrypcja tych genów jest hamowana wysoką zawartością siarczanów oraz glutationu, natomiast stymulowana wysoką zawartością O-acetyloseryny (Terry i wsp. 2000). Transportery niskiego powinowactwa zlokalizowane są w korzeniach oraz liściach i zaangażowane są w transport jonów z roztworu glebowego do korzenia, jak również uczestniczą $\mathrm{w}$ międzykomórkowym transporcie z apoplastu do symplastu (Handa 2016). Badania na roślinach $\mathrm{z}$ nadekspresją genów kodujących transportery wysokiego powinowactwa lub niskiego powinowactwa, wykazały wzrost akumulacji selenianu u mutantów z nadekspresją genów kodujących transportery wysokiego powinowactwa w porównaniu z roślinami dzikimi. Sugeruje to zaangażo- wanie tych transporterów w pobieraniu selenu w formie selenianu (Terry i wsp. 2000). W przeciwieństwie do selenia$\mathrm{nu}$, selen $\mathrm{w}$ formie seleninu transportowany jest $\mathrm{z}$ roztworu glebowego do komórek korzenia na zasadzie dyfuzji biernej. Sugeruje się jednak, iż w jego pobieraniu mogą uczestniczyć również transportery fosforanów (Hawrylak-Nowak 2015; Handa 2016).

\section{Toksyczność selenu w roślinie / Selenium toxicity in the plant}

Nadmierne ilości selenu powodują chlorozy, nekrozy, hamowanie rozwoju pędów i korzeni (Terry i wsp. 2000; Van Hoewyk 2013; Kolbert i wsp. 2016). Selen najsilniej oddziałuje na system korzeniowy, ograniczając wzrost korzeni włośnikowych oraz elongację korzenia (Kolbert i wsp. 2016). Stopień zahamowania wzrostu korzenia odzwierciedla podatność bądź odporność gatunków na działanie związków selenu i może być traktowany jako wskaźnik tolerancji selenu (Fisher i wsp. 2016; Kolbert i wsp. 2016). W badaniach na mutantach Arabidopsis wykazano, iż selenian wpływał na obniżenie aktywności genów odpowiedzialnych za syntezę komponentów ściany komórkowej oraz białek regulowanych auksyną, a tym samym hamował wzrost i rozwój roślin (Van Hoewyk i wsp. 2008).

Nagromadzenie toksycznych ilości selenu powoduje również zmniejszenie efektywności fotosyntezy, a w dalszej kolejności prowadzi do śmierci rośliny (Van Hoewyk 2013). Poza zróżnicowaną wrażliwością poszczególnych gatunków i zdolnością do akumulacji selenu, na toksyczność tego pierwiastka ma wpływ również wiek rośliny, ponieważ większą wrażliwością charakteryzują się rośliny młode, a także forma, w jakiej selen występuje. Uważa się, iż selenin jest formą bardziej toksyczną niż selenian (Garousi 2015; Kolbert i wsp. 2016).

Pobrane przez roślinę nieorganiczne formy selenu mogą być przyłączane na szlaku asymilacji siarki do cysteiny oraz do metioniny, bądź do innych nieorganicznych związków w miejsce siarki, w czym upatruje się toksyczne działanie selenu (Mehdawi i Pilon-Smits 2012; Van Hoewyk 2013; Dimkovikj i wsp. 2015; Kolbert i wsp. 2016; White 2018). Niespecyficzne włączanie selenocysteiny oraz selenometioniny do białek powoduje ich dysfunkcje (Pickering i wsp. 2003; Van Hoewyk i wsp. 2008; Pilon-Smits i Quinn 2010; Van Hoewyk 2013; Dimkovikj i wsp. 2015; Pilon-Smits 2015; Gupta i Gupta 2017; Lima i wsp. 2018). Cysteina jest niezbędna do tworzenia mostków dwusiarczkowych utrzymujących struktury białek i mających udział w ich regulacji potranslacyjnej, jak w przypadku tioredoksyny, dlatego też zastąpienie cysteiny selenocysteiną może prowadzić do zniekształcania struktury białka (Schurmann i Jacquot 2000; Sabbagh i Van Hoewyk 2012). Błędne włączanie selenocysteiny 
do białek wykazano w badaniach na Vigna radiata (Brown i Shrift 1980; Van Hoewyk 2013). Wykazano, iż podczas translacji tRNA ${ }^{\text {cys }}$ przypadkowo wiąże się z selenocysteiną zamiast z cysteiną (Van Hoewyk i wsp. 2008; Van Hoewyk 2013). W chloroplastach selenocysteina może również ulegać przekształceniu do selenometioniny przy udziale enzymu o aktywności selenocystazyny i być włączana do białek z mniej szkodliwym skutkiem (Pilon-Smits i Quinn 2010; Van Hoewyk 2013). Przemiany enzymatyczne selenometioniny dają jako ostateczne produkty lotne - dimetyloselenek u roślin niebędących akumulatorami selenu oraz dimetylodiselenek u hiperakumulatorów (Pilon-Smits i Quinn i wsp. 2010; Gupta i Gupta 2017). Metylacja selenocysteiny i selenometioniny oraz ich konwersja do związków lotnych są strategią roślin ograniczającą toksyczność selenu, ponieważ metylowane formy selenu (dimetyloselenek i dimetylodiselenek) odznaczają się 500-700-krotnie mniejszą toksycznością niż selen w formie nieorganicznej (Marecik i wsp. 2006; White 2018). Obecność metylotransferazy selenocysteiny, która metyluje selenocysteinę, zapobiegając jej włączaniu w struktury białek, wykazano u Stanleya pinnata i Astragalus bisulcatus będących hiperakumulatorami selenu (Freeman i wsp. 2010; Sabbagh i Van Hoewyk 2012). Ponadto wykazana u Arabidopsis, Astralagus bisulcatus i Brassica juncea nadekspresja metylotransferazy selenocysteiny zwiększała tolerancję roślin na selen oraz jego akumulację i ulatnianie (LeDuc i wsp. 2004; Sabbagh i Van Hoewyk 2012).

Oprócz powstawania nieswoistych białek o zaburzonych funkcjach, selen może również wpływać na rośliny działając jako czynnik abiotyczny wywołujący stres oksydacyjny poprzez zmniejszenie ilości glutationu w komórkach roślinnych oraz zwiększenie generowania rodnika ponadtlenkowego, powodując tym samym zmiany metaboliczne i uszkodzenia struktur komórkowych (Sabbagh i Van Hoewyk 2012; Van Hoewyk 2013; Dimkovikj i wsp. 2015; Lima i wsp. 2018; White 2018).

\section{Rola selenu w tolerancji roślin na czynniki stresowe / The role of selenium in plant tolerance to stress factors}

Różne czynniki stresu biotycznego i abiotycznego, w tym żerowanie fitofagów, indukują w roślinach stres oksydacyjny, który jest jedną z najwcześniejszych uniwersalnych reakcji komórek ujawnionych przez gwałtowny wzrost wewnątrzkomórkowego poziomu reaktywnych form tlenu (RFT) w postaci m.in. nadtlenku wodoru, anionu ponadtlenkowego i rodnika hydroksylowego (Dat i wsp. 2000; Van Breusegem i Dat 2006). Dla prawidłowego przebiegu procesów metabolicznych konieczne jest utrzymanie równowagi między generowaniem RFT a ich usuwaniem. Stres oksydacyjny polega na zaburzeniu równowagi między po- wstawaniem i degradacją RFT. Rośliny posiadają system antyoksydacyjny złożony z małocząsteczkowych przeciwutleniaczy (m.in. askorbinianu, glutationu, karotenoidów, antocyjanów) i enzymów przeciwutleniających (m.in. dysmutazy ponadtlenkowej, katalazy, peroksydaz), które usuwają nadmiar RFT, a tym samym minimalizują i zapobiegają postępującemu uszkodzeniu elementów komórkowych. Jednakże, gdy ilość RFT przewyższa skuteczność systemu antyoksydacyjnego, mogą wystąpić zmiany w komórkach powodujące uszkodzenie, w tym utlenienie grup tiolowych białek, peroksydacja lipidów i rozerwanie nici DNA. Selen w niskiej koncentracji może wspomagać odporność roślin na działanie czynników stresowych, takich jak niska temperatura (Abbas 2012; Akladious 2012), wysoka temperatura (Iqbal i wsp. 2015), deficyt wody (Yao i wsp. 2009; Habibi 2013), promieniowanie UV-B (Mostafa i Hassan 2015) czy zasolenie (Kong i wsp. 2005; Shalaby i wsp. 2017) działając jako przeciwutleniacz bądź wpływając na elementy systemu antyoksydacyjnego (Hasanuzzaman i wsp. 2010; DomokosSzabolcsy i wsp. 2017). Traktowanie roślin selenem w celu wspomagania ich odporności na czynniki stresowe może stanowić przykład biostymulacji, czyli zwiększania naturalnego potencjału roślin. U roślin traktowanych związkami selenu stwierdzono zwiększenie aktywności enzymów usuwających nadtlenek wodoru, takich jak peroksydaza askorbinianowa i peroksydaza glutationowa, a także wzrost zawartości przeciwutleniaczy, takich jak askorbinian i glutation (Ríos i wsp. 2009; Habibi 2013).

Rośliny sorgo (Sorghum bicolor) poddane działaniu niskich temperatur i traktowane selenianem, charakteryzowały się większą zawartością antocyjanów, askorbinianu oraz karotenoidów w porównaniu do kontroli (Abbas 2012). Wykazano również, iż wstępne traktowanie ziarniaków pszenicy (Triticum aestivum) roztworem selenianu wpływało na lepszą adaptację roślin do niskich temperatur, poprzez zwiększenie zawartości przeciwutleniaczy m.in. antocyjanów i askorbinianu oraz aktywności katalazy (Akladious 2012). Ponadto zaobserwowano, iż selen u sałaty (Lectuca sativa) traktowanej niskimi temperaturami zmniejszał peroksydację lipidów, ograniczając tym samym uszkodzenia błon komórkowych (Mervi i wsp. 2003; Akladious 2012). Podobne obserwacje uzyskano badając osie zarodkowe nasion klonu srebrzystego (Acer saccharinum) poddane stresowi suszy (Pukacka i wsp. 2011).

Badania na pszenicy narażonej na działanie wysokich temperatur wykazały, iż selen powoduje zarówno zwiększenie aktywności enzymów antyoksydacyjnych, tj. peroksydazy i katalazy, jak i zawartości nieenzymatycznych antyoksydantów (karotenoidów, antocyjanów i askorbinianu), a jednocześnie zmniejszenie zawartości nadtlenku wodoru i aldehydu malonowego - produktu peroksydacji lipidów (Iqbal i wsp. 2015).

$\mathrm{W}$ badaniach nad wpływem promieniowania UV-B na paproć wodną (Azolla caroliniana), dodatek selenu do po- 
żywki powodował w tkankach rośliny znaczne zwiększenie całkowitej zawartości askorbinianu i glutationu oraz wzrost potencjału oksydoredukcyjnego glutationu w porównaniu do roślin kontrolnych bez UV-B oraz nietraktowanych Se i poddanych działaniu promieniowania (Mostafa i Hassan 2015).

W warunkach stresu zasolenia wykazano, iż traktowanie selenem roślin sałaty (L. sativa) powodowało zwiększenie aktywności katalazy i peroksydazy askorbinianowej w porównaniu do roślin kontrolnych (Shalaby i wsp. 2017). Ponadto rośliny traktowane selenem miały większą suchą masę i powierzchnię liści (Shalaby i wsp. 2017). W liścieniach szczawiu (Rumex patientia $\times$ Rumex tianshanicus) traktowanych selenem w warunkach zasolenia wykazano wzrost aktywności enzymów dysmutazy ponadtlenkowej i peroksydaz (Kong i wsp. 2005).

Analizując rolę selenu $\mathrm{w}$ tolerancji roślin na czynniki stresowe zwraca się również uwagę na wpływ selenu na pobieranie kofaktorów niektórych enzymów antyoksydacyjnych, takich jak: $\mathrm{Cu}, \mathrm{Fe}, \mathrm{Mo}, \mathrm{Mn}$ i $\mathrm{Zn}$ oraz na aktywność dysmutazy ponadtlenkowej (SOD) - chloroplastowej $\mathrm{CuZnSOD}$ oraz mitochondrialnej MnSOD (Domokos-Szabolcsy i wsp. 2017).

\section{Elemental Defense Hypothesis}

Rośliny wytworzyły szereg strategii obronnych mających uchronić je przed żerowaniem roślinożerców. Jedną ze strategii obronnych - ochrona przed roślinożercami oraz patogenami niektórych gatunków roślin, nazwana Elemental Defense Hypothesis - jest zdolność akumulowania pierwiastków śladowych, takich jak arsen, kadm, nikiel, cynk i selen, do poziomów o kilka rzędów wielkości wyższych niż u innych gatunków rosnących na tym samym stanowisku, bez wykazania objawów toksyczności (Boyd i Martens 1998; Reeves 2006; Boyd 2007; Noret i wsp. 2007; Quinn i wsp. 2010; Jason i wsp. 2018). W roku 1992 Boyd i Martens zaproponowali hiperakumulację pierwiastków śladowych jako specyficzny rodzaj obrony, której mechanizmy różnią się od innych strategii obronnych, ponieważ nie dotyczą metabolitów wytworzonych przez roślinę, a pobranego z gleby pierwiastka. Ponadto koncentracji tego pierwiastka nie można obniżyć, co może mieć miejsce w przypadku metabolitów wtórnych. Rośliny będące hiperakumulatorami mają zwiększoną szybkość pobierania pierwiastków śladowych oraz ich translokacji z korzeni do pędu oraz posiadają większą zdolność detoksykacji oraz sekwestracji w liściach (Verbruggen i wsp. 2009; Rascio i Navari-Izzo 2011). Około 450 gatunków roślin okrytozalążkowych zaliczanych jest do hiperakumulatorów pierwiastków śladowych, co stanowi mniej niż 0,2\% wszystkich znanych gatunków (Rascio i Navari-Izzo 2011).

Elemental Defense Hypothesis zainicjowała nowy trend badań nad obronną rolą pierwiastków śladowych w rośli- nach różnych gatunków, nie tylko zaliczanych do hiperakumulatorów.

\section{Akumulacja selenu w tkankach roślinnych a żerowanie fitofagów / Accumulation of selenium in plant tissues and feeding of phytophages}

U roślin będących hiperakumulatorami selenu wykazano większą ekspresję genów zaangażowanych w reakcje przeciwutleniające oraz odporność na stres biotyczny (Lima i wsp. 2018). Korzystny wpływ selenu na strategie obronne rośliny przed patogenami oraz roślinożercami może wskazywać, iż rośliny mogły ewaluować w kierunku hiperakumulacji (Lima i wsp. 2018). Akumulacja selenu w tkankach roślinnych może zniechęcać organizmy roślinożerne, do pobierania przez nie pokarmu (Mehdawi i wsp. 2011). Selen może oddziaływać deterentnie zniechęcając do żerowania, jak również decydować o wyborze rośliny żywicielskiej (Mechora i Ugrinović 2015). Należy podkreślić, iż selen nie odstrasza potencjalnych zapylaczy, jednakże może wpływać negatywnie na owady zapylające kwiaty, z uwagi na zawartość selenu w pyłku (Quinn i wsp. 2011).

Stwierdzono, iż obecność związków selenu w roślinach zniechęca do żerowania gąsienice światłówki naziemnicy (Spodoptera exigua Hubner) (Vickerman i Trumble 1999), błyszczki ni (Trichoplusia ni Hubner) (Bañuelos i wsp. 2002) oraz bielinka rzepnika (Pieris rapae) (Hanson i wsp. 2003). Ponadto wykazano, że nieorganiczne formy selenu działają silniej deterentnie na larwy światłówki naziemnicy, niż formy organiczne (Vickerman i Trumble 1999). Zawartość selenu w roślinach odstrasza larwy bielinka rzepnika, ale również wpływa na nie toksycznie (Hanson i wsp. 2003). Deterentne działanie selenu stwierdzono również w przypadku fitofagów żywiących się sokiem floemowym. W testach wyboru na mszycy brzoskwiniowej (Myzus persicae) wykazano, iż mszyce preferują rośliny rosnące na pożywkach bez dodatku selenu od roślin wzbogaconych tym pierwiastkiem (Hanson i wsp. 2004). Ograniczenie żerowania mszyc na roślinach zawierających zwiększoną zawartość selenu może być spowodowane nie tylko deterentnym, ale i toksycznym jego wpływem. Nie wyklucza się również dwojakiego charakteru oddziaływania selenu na owady (Hanson i wsp. 2004). Larwy tantnisia krzyżowiaczka (Plutella xylostella) są w stanie żerować na roślinach zawierających selen w wysoce toksycznej koncentracji. Mechanizm tolerancji opiera się na gromadzeniu przez te owady selenu w postaci metyloselenocysteiny, stosunkowo nietoksycznej formy gromadzonej również przez hiperakumulatory. Ponadto wykazano, że tolerująca selen pasożytnicza błonkówka Diadegma insulare, będąca parazytoidem tantnisia krzyżowiaczka, również gromadzi metyloselenocysteinę (Freeman i wsp. 2006). Natomiast 
wrażliwy na selen mutant tantnisia krzyżowiaczka (Plutella xylostella G88) gromadził selenocysteinę (Freeman i wsp. 2006). Gromadzenie metyloselenocysteiny wykazano również u przędziorka chmielowca, który tolerował stężenie $150 \mathrm{mg} \mathrm{Se} / \mathrm{kg}$ s.m., toksyczne dla wielu organizmów roślinożernych. Dopiero po przekroczeniu wartości $420 \mathrm{mg} \mathrm{Se} / \mathrm{kg} \mathrm{s.m.} \mathrm{widoczne} \mathrm{jest} \mathrm{toksyczne} \mathrm{działanie} \mathrm{selenu}$ na tego fitofaga (Quinn i wsp. 2010).

$\mathrm{W}$ doświadczeniach z dwoma gatunkami roślin będących hiperakumulatorami selenu - Astragalus bisulcatus i Stanleya pinnata zasiedlanych przez wciornastka zachodniego (Frankliniella occidentalis) oraz przędziorka chmielowca (Tetranychus urticae) wykazano, iż rośliny o wysokim stężeniu Se (powyżej $650 \mathrm{mg} \mathrm{Se} / \mathrm{kg}$ ) były mniej podatne na zasiedlanie przez szkodniki niż rośliny o niskim poziomie Se (poniżej $150 \mathrm{mg} \mathrm{Se/kg).} \mathrm{Zaobserwowano} \mathrm{również} \mathrm{ogra-}$ niczenie liczebności populacji po zwiększeniu stężenia selenu podawanego roślinom (Quinn i wsp. 2010).

\section{Akumulacja selenu a rozwój fitofagów / Accumulation of selenium and phytophage development}

Nieliczne doniesienia naukowe wskazują, że selen może ograniczać reprodukcję owadów oraz powodować ich śmierć. Wykazano ograniczenie wzrostu oraz zmniejszenie przeżywalności światłówki naziemnicy (Spodoptera exigua) żerującej na bogatych w selen roślinach łobody (Atriplex) (Vickerman i wsp. 2002a). W badaniach na lucernie siewnej (Medicago sativa) wykazano, iż wysokie dawki selenu znacząco ograniczają przepoczwarczanie światłówki naziemnicy (Spodoptera exigua) (Vickerman i wsp. 2002b). U owadów zasiedlających rośliny wzbogacone selenem, nie dochodziło do zakończenia cyklu rozwojowego, śmierć owadów następowała we wczesnych stadiach larwalnych (Vickerman i wsp. 2002b). Wykazano ograniczenie przeżywalności larw o około 70-75\% (Vickerman i Trumble 1999; Mechora 2019). Ponadto dodatek selenu powodował zmniejszenie masy pupariów Spodoptera exigua oraz wydłużał czas wymagany do ukończenia stadium larwalnego o $25 \%$ oraz czas od pojawienia się jaja do form dorosłych o 22-30\% (Trumble i wsp. 1998). W badaniach na błyszczce ni (T. ni) wykazano zahamowanie wzrostu larw o $40 \%$ w wariantach z selenem (Popham i wsp. 2005; Mechora 2019). Wpływ selenu na rozwój larw zaobserwowano również w badaniach na larwach bielinka kapustnika (Pieris rapae) żerujących na kapuście. Młode larwy umieszczane na roślinach wzbogaconych w selen umierały po 9 dniach żerowania, natomiast starsze larwy po 2 dniach (Hanson i wsp. 2003; Mechora 2019). Śmietka kapuściana (Delia radicum) składała tyle samo jaj na roślinach z dodatkiem selenu co na roślinach kontrolnych, jednakże w późniejszych obserwacjach w kombinacjach z dodatkiem selenu stwierdzono mniejszą ilość pupariów (Mechora i wsp. 2017; Mechora 2019).

W związku z rosnącym zainteresowaniem biofortyfikacją roślin uprawnych selenem konieczne jest wnikliwe rozpoznanie wpływu tego pierwiastka na parametry życiowe oraz żerowanie fitofagów, gdyż deterentność i toksyczność selenu względem fitofagów może wywierać wpływ na relacje troficzne wewnątrz agro- i ekosystemów.

\section{Literatura / References}

Abbas S.M. 2012. Effects of low temperature and selenium application on growth and the physiological changes in sorghum seedlings. Journal of Stress Physiology and Biochemistry 8 (1): 268-286.

Akladious S.A. 2012. Influence of different soaking times with selenium on growth, metabolic activities of wheat seedlings under low temperature stress. African Journal of Biotechnology 11 (82): 14792-14804. DOI: 10.5897/AJB12.2140

Bañuelos G.S., Arroyoa I., Pickering I.J., Yang S.I., Freeman J.L. 2015. Selenium biofortification of broccoli and carrots grown in soil amended with Se-enriched hyperaccumulator Stanleya pinnata. Food Chemistry 166: 603-608. DOI: 10.1016/j.foodchem.2014.06.071

Bañuelos G.S., Vickerman D.B., Trumble J.T., Shannon M.C., Davis C.D., Finley J.W., Mayland H.F. 2002. Biotransfer possibilities of selenium from plants used in phytoremediation. International Journal of Phytoremediation 4 (4): 315-331. DOI: $10.1080 / 15226510208500090$

Bodnar M., Konieczka P., Namiesnik J. 2012. The properties, functions, and use of selenium compounds in living organisms. Journal of Environmental Science and Health, Part C 30 (3): 225-252. DOI: 10.1080/10590501.2012.705164

Boyd R.S. 2007. The defense hypothesis of elemental hyperaccumulation: status, challenges and new directions. Plant and Soil 293: 153-176. DOI: 10.1007/s11104-007-9240-6

Boyd R.S., Martens S.N. 1998. The significance of metal hyperaccumulation for biotic interactions. Chemoecology 8: 1-7. DOI: 10.1007/ s000490050002

Broadley M.R., Alcock J., Alford J., Cartwright P., Foot I., Fairweather-Tait S.J., Hart D.J., Hurst R., Knott P., McGrath S.P., Meacham M.C., Norman K., Mowat H., Scott P., Stroud J.L., Tovey M., Tucker M., White P.J., Young S.D., Zhao F.J. 2010. Selenium biofortification of high-yielding winter wheat (Triticum aestivum L.) by liquid or granular Se fertilisation. Plant and Soil 332: 5-18. DOI: 10.1007/ s11104-009-0234-4

Brown T.A., Shrift A. 1980. Identification of selenocysteine in the proteins of selenate-grown Vigna radiata. Plant Physiology 66: 758-761. DOI: $10.1104 / \mathrm{pp} .66 .4 .758$

Brown T.A., Shrift A. 1981. Exclusion of selenium from proteins in selenium-tolerant Astragalus species. Plant Physiology 67: $1951-1953$. DOI: $10.1104 / p p \cdot 67.5 .1051$ 
Chilimba A.D.C., Young S.D., Black C.R., Meacham M.C., Lammel J., Broadley M.R. 2012. Agronomic biofortification of maize with selenium (Se) in Malawi. Field Crops Research 125: 118-128. DOI: 10.1016/j.fcr.2011.08.014

Dat J., Vandenabeele S., Vranová E., Van Montagu M., Inzé D., van Breusegem F. 2000. Dual action of the active oxygen species during plant stress responses. Cellular and Molecular Life Sciences 57: 779-795. DOI: 10.1007/s000180050041

Dimkovikj A., Fisher B., Hutchison K., Van Hoewyk D. 2015. Stuck between a ROS and a hard place: Analysis of the ubiquitin proteasome pathway in selenocysteine treated Brassica napus reveals different toxicities during selenium assimilation. Journal of Plant Physiology 181: 50-54. DOI: 10.1016/j.jplph.2015.04.003

Domokos-Szabolcsy E., Alshaal T., Elhawat N., Abdalla N., Dos Reis A.R., El-Ramady H. 2017. The interactions between selenium, nutrients and heavy metals in higher plants under abiotic stresses. Enviroment Biodiversity and Soil Security 1: 5-31. DOI: 10.21608/ jenvbs.2017.951.1001

El Kassis E., Cathala N., Rouached H., Fourcroy P., Berthomieu P., Terry N. 2007. Characterization of a selenate-resistant Arabidopsis mutant: root growth as a potential target for selenate toxicity. Plant Physiology 143 (3): 1231-1241. DOI: 10.1104/pp.106.091462

Fisher B., Yarmolinsky D., Abdel-Gany S., Pilon M., Pilon-Smits E.A., Sagi M., Van Hoewyk D. 2016. Superoxide generated from the glutathione-mediated reduction of selenite damages the iron-sulphur cluster of chloroplastic ferredoxin. Plant Physiology and Biochemistry 106: 228-235. DOI: 10.1016/j.plaphy.2016.05.004

Freeman J.L., Quinn C.F., Marcus M.A., Fakra S., Pilon-Smits E.A.H. 2006. Selenium tolerant diamondback moth disarms hyperaccumulator plant defense. Current Biology 16 (22): 2181-2192. DOI: 10.1016/j.cub.2006.09.015

Freeman J.L., Tamaoki M., Stushnoff C., Quinn C.F., Cappa J.J., Devonshire J. 2010. Molecular mechanisms of selenium tolerance and hyperaccumulation in Stanleya pinnata. Plant Physiology 153: 1630-1652. DOI: 10.1104/pp.110.156570

Galeas M.L., Zhang L.H., Freeman J.L., Wegner M., Pilon-Smits E.A.H. 2007. Seasonal fluctuations of selenium and sulfur accumulation in selenium-hyperaccumulators and related non-accumulators. New Phytologist 173 (3): 517-525. DOI: 10.1111/j.1469-8137. 2006.01943.x

Garousi F. 2015. The toxicity of different selenium forms and compounds. Review. Agrártudományi Közlemények 64: 33-38.

Gupta M., Gupta S. 2017. An overview of selenium uptake, metabolism and toxicity in plants. Frontiers in Plant Science 7 (2074): 1-14. DOI: $10.3389 /$ fpls.2016.02074

Habibi G. 2013. Effect of drought stress and selenium spraying on photosynthesis and antioxidant activity of spring barley. Acta Agriculturae Slovenica 101: 31-39. DOI: 10.2478/acas-2013-0004

Handa N. 2016. Selenium: an antioxidative protectant in plants under stress. s. 179-207. W: Plant Metal Interaction: Emerging Remediation Techniques (P. Ahmad, red.). Elsevier Science Publisher, Amsterdam, Nederlands, 619 ss. DOI: 10.1016/B978-0-12803158-2.00007-2

Hanson B., Garifullina G.F., Lindblom S.D., Wangeline A., Ackley A., Kramer K., Norton A.P., Lawrence C.B., Pilon-Smits E.A.H. 2003. Selenium accumulation protects Brassica juncea from invertebrate herbivory and fungal infection. New Phytology 159 (2): $461-469$. DOI: $10.1046 / j .1469-8137.2003 .00786 . x$

Hanson B., Lindblom S.D., Loeffler M.L., Pilon-Smits E.A.H. 2004. Selenium protects plants from phloem-feeding aphids due to both deterrence and toxicity. New Phytologist 162 (3): 655-662. DOI: 10.1111/j.1469-8137.2004.01067.x

Hasanuzzaman M., Hossain M.A., Fujita M. 2010. Selenium in higher plants: physiological role, antioxidant metabolism and abiotic stress tolerance. Journal of Plant Science 5 (4): 354-375. DOI: 10.3923/jps.2010.354.375

Hawrylak-Nowak B. 2015. The dual effects of two inorganic selenium forms on the growth, selected physiological parameters and macronutrients accumulation in cucumber plants. Acta Physiologiae Plantarum 37: 41. DOI: 10.1007/s11738-015-1788-9

Iqbal M., Hussain I., Liaqat H., Ashraa M.A., Rasheed R., Ur Rehman A. 2015. Exogenously applied selenium reduces oxidative stress and induces heat tolerance in spring wheat. Plant Physiology and Biochemistry 94: 95-103. DOI: 10.1016/j.plaphy.2015.05.012

Jason R., Reynolds B., Pilon-Smits E.A.H. 2018. Plant selenium hyperaccumulation - Ecological effects and potential implications for selenium cycling and community structure. Biochimica et Biophysica Acta - General Subjects 1862 (11): 2372-2382. DOI: 10.1016/j. bbagen.2018.04.018

Jianwei W., Zhaohui W., Hui M., Hubing Z., Donglin H. 2013. Increasing Se concentration in maize grain with soil- or foliar-applied selenite on the Loess Plateau in China. Field Crops Research 150: 83-90. DOI: 10.1016/j.fcr.2013.06.010

Kolbert Z., Lehotai N., Molnár A., Feigl G. 2016. "The roots" of selenium toxicity: A new concept. Plant Signaling and Behaviour 11 (10): e1241935.

Kong L., Wang M., Bi D. 2005. Selenium modulates the activities of antioxidant enzymes, osmotic homeostasis and promotes the growth of sorrel seedlings under salt stress. Plant Growth Regulation 45: 155-163. DOI: 10.1007/s10725-005-1893-7

LeDuc D.L., Tarun A.S., Montes-Bayon M., Meija J., Malit M.F., Wu C.P., Abede I., Samie M., Chiang C.Y., Tagmount A., De Souza M., Neuhierl B., Bock A., Caruso J., Terry N. 2004. Overexpression of selenocysteine methyltransferase in Arabidopsis and Indian mustard increases selenium tolerance and accumulation. Plant Physiology 135: 377-383. DOI: 10.1104/pp.103.026989

Lidon F.C., Oliveira K., Ribeiro M.M., Pelica J., Pataco I., Ramalho J.C., Leitã A.E., Almeida A.S., Campos P.S., Ribeiro-Barros I.A., Paisc I.P., Silva M.M., Pessoa M.F., Reboredoa F.H. 2018. Selenium biofortification of rice grains and implications on macronutrients quality. Journal of Cereal Science 81: 22-29. DOI: 10.1016/j.jcs.2018.03.010

Lima L.W., Pilon-Smits E.A.H., Schiavon M. 2018. Mechanisms of selenium hyperaccumulation in plants: A survey of molecular, biochemical and ecological cues. Biochimica et Biophysica Acta - General Subjects 1862 (11): 2343-2353. DOI: 10.1016/j.bbagen. 2018.03.028

Marecik R., Króliczak P., Cyplik P. 2006. Fitoremediacja - alternatywa dla tradycyjnych metod oczyszczania środowiska. Biotechnologia 3 (74): 88-97.

Mechora S. 2019. Selenium as a protective agent against pests: a review. Plants 8 (8): e262. DOI: 10.3390/plants8080262

Mechora Š., Torres D., Bruns R.E., Škof M., Ugrinović K. 2017. Effect of selenium treated broccoli on herbivory and oviposition preferences of Delia radicum and Phyllotreta spp. Scientia Horticularae 225: 445-453. DOI: 10.1016/j.scienta.2017.07.032

Mechora Š., Ugrinović K. 2015. Can plant-herbivore interaction be affected by selenium? Austin Journal of Environmental Toxicology 1 (1): 5.

Mehdawi A.F., Pilon-Smits E.A.H. 2012. Ecological aspects of plant selenium hyperaccumulation. Plant Biology 14: 1-10. DOI: 10.1111/ j.1438-8677.2011.00535.x 
Mehdawi A.F., Quinn C.F., Pilon-Smits E.A.H. 2011. Selenium hyperaccumulators facilitate selenium-tolerant neighbors via phytoenrichment and reduced herbivory. Current Biology 21 (17): 1440-1449. DOI: 10.1016/j.cub.2011.07.033

Mervi S., Marja T., Helinä H. 2003. Selenium effects on oxidative stress in potato. Plant Science 165 (2): 311-319. DOI: 10.1016/S01689452(03)00085-2

Mostafa E., Hassan A. 2015. The ameliorative effect of selenium on Azolla caroliniana grown under UV-B stress. Phytoprotection 95 (1): 20-26. DOI: 10.7202/1031954ar

Noret N., Meerts P., Vanhaelen M., Dos Santos A., Escarré J. 2007. Do metal-rich plants deter herbivores? A field test of the defence hypothesis. Oecologia 152 (1): 92-100. DOI: 10.1007/s00442-006-0635-5

Pickering I.J., Wright C., Bubner B., Ellis D., Persans M.W., Yu E.Y., George G.N., Prince R.C., Salt D.E. 2003. Chemical form and distribution of selenium and sulfur in the selenium hyperaccumulator Astragalus bisulcatus. Plant Physiology 131: 1460-1467. DOI: 10.1104/pp.014787

Pilon-Smits E.A.H. 2015. Selenium in plants. Progress in Botany 76: 93-107.

Pilon-Smits E.A.H., Quinn C.F. 2010. Selenium metabolism in plants. s. 225-241. W: Cell Biology of Metals and Nutrients. Plant Cell Monographs 17 (R. Hell, R. Mendel, red.). Springer, Berlin, 304 ss.

Poblacionesa M.J., Rodrigoa S., Santamaríaa O., Chenb Y., McGrathb S.P. 2014. Agronomic selenium biofortification in Triticum durum under Mediterranean conditions: From grain to cooked pasta. Food Chemistry 146: 378-384. DOI: 10.1016/j.foodchem.2013.09.070

Popham H.J.R., Shelbya K.S., Popham T.W. 2005. Effect of dietary selenium supplementation on resistance to baculovirus infection. Biological Control 32 (3): 419-426. DOI: 10.1016/j.biocontrol.2004.12.011

Pukacka S., Ratajczak E., Kalemba E. 2011. The protective role of selenium in recalcitrant Acer saccharium L. seeds subjected to desiccation. Journal of Plant Physiology 168 (3): 220-225. DOI: 10.1016/j.jplph.2010.07.021

Quinn C.F., Freeman J.L., Reynolds R.J.B., Cappa J.J., Fakra S.C., Marcus M.A., Lindblom S.D., Quinn E.K., Bennett L.E., Pilon-Smits E.A.H. 2010. Selenium hyperaccumulation offers protection from cell disruptor herbivores. BMC Ecology 10: 19. DOI: 10.1186/1472$6785-10-19$

Quinn C.F., Prins C.N., Freeman J.L., Gross A.M., Hantzis L.J., Reynolds R.J.B., Yang S., Covej P.A., Bañuelos G.S., Pickering I.J.M., Pilon-Smits E.A.H. 2011. Selenium accumulation in flowers and its effect on pollination. New Phytologist 192: 727-737.

Ramos S.J., Faquin V., Guilherme L.R.G., Castro E.M., Ávila F.W., Carvalho G.S., Bastos C.E.A., Oliveira C. 2010. Selenium biofortification and antioxidant activity in lettuce plants fed with selenate and selenite. Plant and Soil Environment 56: 584-588. DOI: 10.17221/113/2010-PSE

Rascio N., Navari-Izzo F. 2011. Heavy metal hyperaccumulating plants: How and why they do it? And what makes them so interesting. Plant Science 180 (2): 169-181. DOI: 10.1016/j.plantsci.2010.08.016

Reeves R.D. 2006. Hyperaccumulation of trace elements by plants. s. 1-25. W: Phytoremediation of Metal-Contaminated Soils. NATO Science Series: IV: Earth and Environmental Sciences 68 (J.L. Morel, G. Echevarria, N. Goncharova, red.). Springer, Dordrecht, 346 ss.

Reich H.J., Hondal R.J. 2016. Why nature chose selenium. ACS Chemical Biology 11 (4): 821-841. DOI: 10.1021/acschembio.6b00031

Ríos J.J., Blasco B., Cervilla L.M., Rosales M.A., Sanchez-Rodriguez E., Romero L., Ruiz J.M. 2009. Production and detoxification of $\mathrm{H}_{2} \mathrm{O}_{2}$ in lettuce plants exposed to selenium. Annals of Applied Biology 154: 107-116. DOI: 10.1111/j.1744-7348.2008.00276.x

Ros G.H., van Rotterdam A.M.D., Bussink D.W., Bindraban P.S. 2016. Selenium fertilization strategies for bio-fortification of food: an agro-ecosystem approach. Plant and Soil 404: 99-112. DOI: 10.1007/s11104-016-2830-4

Sabbagh M., Van Hoewyk D. 2012. Malformed selenoproteins are removed by the ubiquitin-proteasome pathway in Stanleya pinnata. Plant and Cell Physiology 53 (3): 555-564. DOI: 10.1093/pcp/pcs015

Schomburg L., Arner E.S.J. 2017. Selenium metabolism in herbivores and higher trophic levels including mammals. s. 123-139. W: Selenium in Plants: Molecular, Physiological, Ecological and Evolutionary Aspects (E.A.H. Pilon-Smits, L.H.E. Winkel, Z.Q. Lin, red.). Springer, Cham, 324 ss.

Schurmann P., Jacquot J.P. 2000. Plant thioredoxin systems revisited. Annual Review of Plant Physiology Plant Molecular Biology 51: 371-400. DOI: 10.1146/annurev.arplant.51.1.371

Shalaby T., Bayoumi Y., Alshaal T., Elhawat N., Sztrik A., El-Ramady H. 2017. Selenium fortification induces growth, antioxidant activity, yield and nutritional quality of lettuce in salt-affected soil using foliar and soil applications. Plant and Soil 421: 245-258. DOI: 10.1007/s11104-017-3458-8

Smoleń S., Skoczylas Ł., Ledwożyw-Smoleń I., Rakoczy R., Kopeć A., Piątkowska E., Bieżanowska-Kopeć R., Pysz M., Koronowicz A., Kapusta-Duch J., Pawłowski T. 2016. Iodine and selenium biofortification of lettuce (Lactuca sativa L.) by soil fertilization with various compounds of these elements. Acta Scientarum Pololonorum, Hortorum Cultus 15 (5): 69-91.

Terry N., Zayed A.M., De Souza M.P., Tarun A.S. 2000. Selenium in higher plants. Annual Review of Plant Physiology and Plant Molecular Biology 51: 401-432. DOI: 10.1146/annurev.arplant.51.1.401

Thavarajah D., Ruszkowski J., Vandenberg A. 2008. High potential for selenium biofortification of lentils (Lens culinaris L.). Journal of Agriculture and Food Chemistry 56 (22): 10747-10753. DOI: 10.1021/jf802307h

Tobe R., Mihara H. 2018. Delivery of selenium to selenophosphate synthetase for selenoprotein biosynthesis. BBA - General Subjects 1862 (11): 2433-2440. DOI: 10.1016/j.bbagen.2018.05.023

Trumble J.T., Kund G.S., White K.K. 1998. Influence of form and quantity of selenium on the development and survival of an insect herbivore. Environmental Pollution 101 (2): 175-182. DOI: 10.1016/S0269-7491(98)00086-4

Van Breusegem F., Dat J.F. 2006. Reactive oxygen species in plant cell death. Plant Physiology 141: 384-390. DOI: 10.1104/ pp.106.078295

Van Hoewyk D. 2013. A tale of two toxicities: malformed selenoproteins and oxidative stress both contribute to selenium stress in plants. Annals of Botany 112 (6): 965-972. DOI: 10.1093/aob/mct163

Van Hoewyk D., Takahashi H., Inoue E., Hess A., Tamaoki M., Pilon Smits E.A.H. 2008. Transcriptome analyses give insights into selenium-stress responses and selenium tolerance mechanisms in Arabidopsis. Physiologia Plantarum 132: 236-253. DOI: 10.1111/ j.1399-3054.2007.01002.x

Verbruggen N., Hermans C., Schat H. 2009. Molecular mechanisms of metal hyperaccumulation in plants. New Phytologist 181: $759-776$. DOI: $10.1111 / \mathrm{j} .1469-8137.2008 .02748 . x$ 
Vickerman D.B., Shannon M.C., Bañuelos G.S., Grieve C.M., Trumble J.T. 2002a. Evaluation of Atriplex lines for selenium accumulation, salt tolerance and suitability for a key agricultural insect pest. Environmental Pollution 120 (2): 463-473. DOI: 10.1016/S02697491(02)00116-1

Vickerman D.B., Trumble J.T. 1999. Feeding preferences of Spodoptera exigua in response to form and concentration of selenium. Archives of Insect Biochemistry and Physiology 42 (1): 64-73. DOI: 10.1002/(SICI)1520-6327(199909)42:1<64::AID-ARCH7>3.0.CO;2-Y

Vickerman D.B., Young J.K., Trumble J.T. 2002b. Effect of selenium-treated alfalfa on development, survival, feeding, and oviposition preferences of Spodoptera exigua (Lepidoptera: Noctuidae). Environmental Entomology 31 (6): 953-959. DOI: 10.1603/0046-225X31.6.953

White P.J. 2018. Selenium metabolism in plants. Biochimica et Biophysica Acta - General Subjects 1862 (11): 2333-2342. DOI: 10.1016/j. bbagen.2018.05.006

White P.J., Bowen H.C., Parmaguru P., Fritz M., Spracklen W.P., Spiby R.E., Meachan M.C., Mead A., Harriman M., Trueman L.J., Smith B.M., Thomas B., Broadley M.R. 2004. Interactions between selenium and sulphur nutrition in Arabidopsis thaliana. Journal of Experimental Botany 55 (404): 1927-1937. DOI: 10.1093/jxb/erh192

Yao X., Chu J., Wang G. 2009. Effects of selenium on wheat seedlings under drought stress. Biological Trace Element Research 130:283-290. DOI: $10.1007 / \mathrm{s} 12011-009-8328-7$ 